\title{
A ROYAL MEDICINE CHEST
}

THE MUSEUM in the little town of Arendal in southern Norway possesses a fine English medicine chest which belonged to Queen Caroline Mathilde of Denmark. On 8 November 1766 this posthumous daughter of George II's eldest son, Frederick, married King Christian VII of Denmark and Norway. Caroline Mathilde was fifteen years old, and Christian VII two years her senior. He had succeeded to the Danish throne a few months before and was already in the grip of a fatal illness, dementia praecox.

The marriage began promisingly, and in 1767 the Queen bore a son, later to become King Frederick VI of Denmark-Norway. A new situation arose in 1768 when Johann Friedrich Struensee (born in Halle in 1737) became court physician. Struensee, under a plausible mask of kindness, concealed a strong personal ambition and soon gained the complete confidence of the young King and Queen. During the summer of 1770 he became Caroline Mathilde's lover, and at the same time gained increasing political influence over Christian VII. By a royal decree of 14 July 1771 he became virtual dictator of the Danish kingdoms. A strong junta now formed against him at the Court and, in 1772, he was arrested, accused of lèse majesté, tortured and beheaded.

The Queen was arrested with him and, after Struensee's confession of their intimate relationship, her marriage to the King was dissolved, and she was exiled to the little Hanoverian town of Celle. She died in 1775 aged 24. King Christian lived on until 1808 , but for the last twenty-four years of his life he was King in name only, while his son acted as Regent.

The medicine chest is a fine example of English cabinet-making. It is made of oak, veneered with mahogany, and is $30 \times 23.5 \times 17 \mathrm{~cm}$. in size. It is fitted on both sides with pigeonholes and oak-lined drawers to hold packets of powder and bottles of medicine. A tray on top is fitted with compartments for instruments etc. The pigeonholes and compartments are lined with green baize and bordered with silk ribbon. A spring mechanism on the lid locks both the back and front doors as well as the lid itself. In general shape and arrangement the chest conforms to the type which was common to the second half of the eighteenth century. It is of superior quality, though not so luxurious as the similar chest, now in the Wellcome Institute of the History of Medicine, which is said to have belonged to the Duke of York, brother of King George III. According to notes, dated 1782 and written on the back of the list of contents, the medicine chest was made up at the Royal Dispensary in London, during October 1776, under the directions of Caroline Mathilde's physician, Johann Gottfried Erichsen. It was for Caroline Mathilde's journey from London to Copenhagen where she was to become Queen of Denmark.

Dr. Erichsen was a German. He received most of his medical training in France, and took his medical doctorate in Halle in 1746. In Denmark he was widely employed by the Government in matters of chemistry and medicine, and, in 1765 was sent to England to study the use of marl as a fertilizer in agriculture. Being already on the spot when Caroline Mathilde needed a medical escort on her journey to Denmark, he became her travelling physician. One of his first duties must have been to make up the medicine chest. 


\section{News, Notes and Queries}

The list of contents (see below) is written by an English hand, presumably at the Royal Dispensary in London, while hurried notes in Gothic script have been added, most probably by Dr. Erichsen himself. Many of the original contents are still present, and they include most of the things usually found in chests of this type. Some items, however, were probably specially selected by Dr. Erichsen, e.g., no. 5, 'Pulv. Antispasmodic: Hall', no. 13, 'Ung Haemorhoidale pr: me', and no. 24, 'Ess. amara Hallensis'.

How did this royal medicine chest find its way to a small Norwegian museum? The written notes on the back of the list of contents are signed by Niles Scythe (1727-1811). He was Erichsen's assistant in the cultivation schemes in Denmark and, after Erichsen's death, the chest came into his possession. Scythe settled in southern Norway in 1770 , and the chest must have passed, directly or indirectly, from him to the prosperous Arendal family of Dedekam, for when in 1832 the Museum in Arendal was established, as the second of its kind in Norway, Mr. Morten Dedekam presented the chest as a gift.

\section{LIST OF CONTENTS OF MEDICINE CHEST}

1. Wund blasun.

2. Emplast Benzoinum.

3. Spirit Lavendul extra

4. Aqua Vulnerar: Lem:

5. pulv. Antispasmodic: Hall.

6. radii Rhabarb.

7. Empl. adhaesivum.

8. Laudan. liq: Syd. cum.

9. Balsam Vulnerar.

10. Sal volat ammon.

11. Liquor. anod min. Hoff.

12. pulv. Solaris/vel aureus.

13. Ung. Haemorhoidale pr: me.

14. pulv. Ipecacuan.

15. Globul moschad:

16. Charpie.
17. pulv. Bezoard. Lond: $v$ Gascoin pouder.

18. pulveres cum Magnes et Rhubarb.

19. Magnesia alba.

20. pulv. cum Tart. Vitr. Crem Tart Nitr. \& Magnesia.

21. pulv. Cort. peruv.

22. pilul. contra obstruct.

23. Radic pyrethri: vel pellitory of Spain.

24. Ess amara Hallensis.

25. Cort. aurantior.

26. Spirit: Cornu Cervi.

27. Spirit Lavend. comp: vel patsy Drops.

28. Tinctur.D: A. de Hugo.

29. Tinct. Rhabarb: vinos:Lond.

30. Tinct. Castorei.

\section{INTERNATIONAL HISTORY OF SCIENCE CONGRESS PARIS, 25-31 AUGUST 1968}

JUST what are the boundaries between the areas covered by the 'history of medicine' and by the 'history of science' is a perennially interesting question and one that is remembered in the light of the proceedings of the XII International History of Science Congress. Much of the large programme of over $\mathbf{4 0 0}$ papers impinged directly on the applications of chemistry and biology to medical problems; for instance, the 